\title{
THE ECONOMIC ESSENCE OF THE INVESTMENT ATTRACTIVENESS OF THE REGIONS
}

\author{
Bohdan Kyshakevych \\ Prof. DSc, Polonia University, \\ e-mail: b_kyshakevych@ukr.net, orcid.org/0000-0001-5721-8543, Poland \\ Marina Nahayeva \\ Post-graduate student, Ivan Franko Drohobych State Pedagogical University, \\ e-mail: nachajevamaryna@ukr.net, orcid.org/0000-0002-0587-6410, Ukraine \\ Andrzej Kryński \\ Professor, Ph.D., Polonia University in Czestochowa, \\ e-mail: a.krynski@ap.edu.pl, orcid.org/0000-0001-9635-023X, Poland
}

\begin{abstract}
The article points out the existence of various approaches to determining the economic nature of investment attractiveness and the investment climate, which complicates the process of both qualitative and quantitative assessment of the attractiveness of regions for potential investors. The authors argued the feasibility of determining the investment attractiveness of the region as a function of the investment climate, investment activity, investment potential and investment risk. A system of investment risks classification and the structure of the investment potential of the region are proposed.
\end{abstract}

Keywords: investment attractiveness, investment climate, business climate, FDI, investment potential, investment risk.

\section{DOI: http://dx.doi.org/10.23856/3704}

\section{Introduction}

The category "investment attractiveness" remains the subject of discussion until today, as there are many interpretations of this term in the economic literature, complicating the process of both qualitative and quantitative assessment of the attractiveness of regions for potential investors. In publications, the term "investment attractiveness" is very often considered identical to such similar concepts as "investment climate", "business climate", "market attractiveness", "investment climate", "investment image" and "investment potential". Although they should considered synonyms, since they carry different semantic sense from an economic point of view.

An analysis of the scientific literature revealed that many authors, addressing the problem of investment attractiveness and the investment climate assessing, do not always interpret their economic essence in the same way. In some works, the investment climate is understood as the degree of auspiciousness of the situation that takes place in a particular region as applied to investments that are planned to be invested in it. Often, the investment climate is also interpreted as the totality of the political, socio-cultural, financial, economic and legal conditions prevailing in the region that determine the quality of the business infrastructure, investment efficiency and the degree of possible risks associated with capital investment. 


\section{Literature reviews and theoretical framework}

According to I. Blank (2006) investment attractiveness and the investment climate can be considered identical, since they complement each other. The attractiveness of the region for investment is proposed by I. Blank in the form of an integral indicator that takes into account the following synthetic valuation characteristics:

- The level of general economic development of the region, estimated on the basis of the following analytical indicators: the share of the region in gross domestic product and national income of the country; the volume of industrial and agricultural products produced in the region per capita; average income of the population and others.

- The level of development of investment infrastructure in the region. The following indicators are taken into account: the number of construction enterprises in the region; volumes of local production of basic building materials; the volume of production of energy resources in the region (in terms of electricity) and others.

- The demographic characteristics of the region estimated on the basis of the following key indicators: the proportion of the region's population in the total population of the country; the ratio of urban and rural residents of the region; the ratio of the employed population; qualification level of the working-age population and others.

- The level of development of market relations and commercial infrastructure in the region which can be estimated on the base of the following indicators: the proportion of nonstate-owned enterprises in the total number of enterprises in the region; the share of products of enterprises of non-state forms of ownership in the total volume of industrial and agricultural products of the region and others.

- The degree of security of investment activity in the region is estimated on the basis of the following indicators: the level of economic crimes per 100 thousand inhabitants of the region; the proportion of construction in progress over the past three years; the proportion of enterprises with harmful emissions, the average radiation background in the cities of the region and others.

According to the technique of I. Blank (2006) the indicators that determine the investment attractiveness of the region, mainly do not have significant volatility, so the frequency of such an assessment could be 3-4 years. N. Tretiak (2013) defines the investment climate as a generalized characteristic of the totality of socio-economic, organizational, legal, political, sociocultural factors that determine the attractiveness and feasibility of investing in a particular object.

K. Malko (2015) considers the investment climate of the state as a combination of political, legal, economic, social, natural, as well as other factors that contribute to the investment activity of domestic and foreign investors.

P. Korenyuk and E. Kopyl (2018) under investment attractiveness understand the ability to achieve a compromise between the investor and the recipient of investments. Moreover, the level of investment attractiveness of an object largely depends on the speed of reaching consensus between the subjects of the investment process.

K. Pokataeva (2007) notes that: "Investment attractiveness is an integral characteristic of the feasibility of investing in potential investment objects, taking into account their investment potential and the specific (microeconomic) and non-specific (macroeconomic) investment risks associated with this process, which, in fact, are the main components of this category". 
S. Kuznetsova and M. Vakulich (2017) under the investment climate understand the mediated state value of the investment environment for a long time. The time period is determined by the statistical range of economic indicators and factors affecting its formation.

An analysis of the existing approaches to understanding the economic essence of the investment attractiveness concepts and the investment climate has shown that despite the fact that they are mutually complementary and have many common features, these concepts cannot be identified, since they represent different concepts from an economic point of view.

V. Litvinova (2014) investment attractiveness and investment climate in the economy compared with weather and climate in physical geography. Weather is the instantaneous value of several characteristics or parameters, and climate is the average value of the weather over a sufficiently long period of time. Similarly, investment attractiveness is considered as an integral characteristic of the investment environment, which reflects the subjective perception of the region by a potential investor and is formed on the basis of an assessment of the investment potential and investment risk of the region. The investment climate of the region is also an integral characteristic of the investment environment, which is formed on the basis of the investment attractiveness of the region for a long period of time.

Despite the fact that many scientists, both domestic and foreign, explore the investment climate and investment attractiveness at the macro- and mesoscale levels, however, up to now there is no unified and economically sound definition of these categories, and moreover in some works they are considered as synonyms.

D. Dolar et al. (2005) and other World Bank experts define the investment climate as an institutional policy and regulatory environment in which the subjects of the investment process function, that is, these are factors that affect the entire cycle of the investment process - from investing to making a profit. If the local government is bureaucratic and corrupt, if the system of state regulation of its own provision or regulation of infrastructure and financial services is ineffective so that companies could not receive reliable services, then the income from potential investments will be low and uncertain.

\section{Factors of Investment Attractiveness}

Western authors very often identify the investment climate and business climate as the same concept. Moreover, modern Western economic theories indicate the special role of the business climate as a fundamental comparative advantage, which stimulates the globalization of production. The mobility of modern business and international companies is growing rapidly today. When analyzing the investment climate, most Western authors have in mind primarily the attractiveness of regions and countries for the receipt of direct foreign investment (FDI). The key factors affecting the dynamics of foreign direct investment are the size of the market and the natural resources of the region.

Most recent Western empirical studies address the issue of assessing the degree of influence of the business climate on FDI inflows, as the business climate is also one of the most important factors on which FDI depends. N. Lahimer (2007) notes the special importance of exogenous factors, such as natural resources. The presence of these factors does not depend on government decisions or the level of development of institutions, especially for countries with high resource availability. So, isolation of the endogenous part of FDI is important for comparing the business climate of several countries, and this raises an important methodological question: how can we empirically isolate the explicative part of the business climate of FDI? 
In the economic literature there is no unambiguous interpretation of the concept of the business climate. This is a multifaceted concept and today there is no clear coherence between various economic and social actors regarding its unambiguous definition.

Erickson (1987) gave one of the most relevant, accurate and concise definitions: "A business climate is the total amount of human resources and capital of a region, including infrastructure, government policy and regulation, which affect the formation and functioning of a commercial enterprise".

Another difference between the concepts of "investment climate" and "investment attractiveness" in our opinion is that the use of the term "investment climate" is correct only in relation to the sphere of potential investments, but not to a specific investment object. The term "investment climate of the company" is not actually used, while the term "investment attractiveness" is an integral assessment that can be applied both at the macro and micro levels.

Thus, having analyzed the existing approaches to understanding the terms "investment climate" and "investment attractiveness", the following main approaches can be distinguished:

1) the investment climate reflects the degree of favorable situation and conditions prevailing in a particular region in relation to investments that can be made in it, that is, in fact, is a synonym for investment attractiveness;

2) the proposed investment climate is interpreted as a set of some investment institutions in the region, formed under the influence of objective factors;

3) the investment climate, together with investment activity is crucial for the formation of the investment attractiveness of the region.

We will continue to adhere to the third approach - to come out of the fact that the investment climate is a key characteristic of the investment process, and it will determine how attractive the region is for the potential investor. Therefore, it is the investment climate that determines the investment attractiveness of the territory or region. Thus, we will consider that the investment attractiveness of the region depends on the investment climate, investment activity, investment cpotential and investment risk, and therefore, it can be considered a function of these variables:

$$
I_{\text {attract }}=F(C, A, P, R)
$$

where $I_{\text {atract }}$ - the investment attractiveness, C - investment climate, A - investment activity, P - investment potential, $\mathrm{R}$ - investment risk.

In the future, the investment climate is understood as a generalized characteristic of the totality of social, economic, organizational, legal, political and other conditions that affect the process of investing in the economy of a country (region).

Since today in the scientific literature you can find a significant number of interpretations not only of investment potential, but also of the economic category "potential" itself, for further quantitative and qualitative analysis of the investment process and investment attractiveness of the regions, it is important to correctly identify and distinguish at least such key concepts as "investment potential", "investment capital", "investment attractiveness". Definition of investment potential proposed by U. Nechitailo (2011) deserves attention - "this is the ability to achieve the desired result through the implementation and management of investment opportunities contained in investment resources, in turn creates a favorable investment climate, which ensures the investment attractiveness of the state and regions in particular". 
In the future we will consider that the investment potential is a quantitative characteristic that takes into account the main macroeconomic indicators, the saturation of the territory with production factors (natural resources, labor, fixed assets, infrastructure, etc.). The investment potential also takes into account the consumer demand of the population and other components presented in Fig. 1.

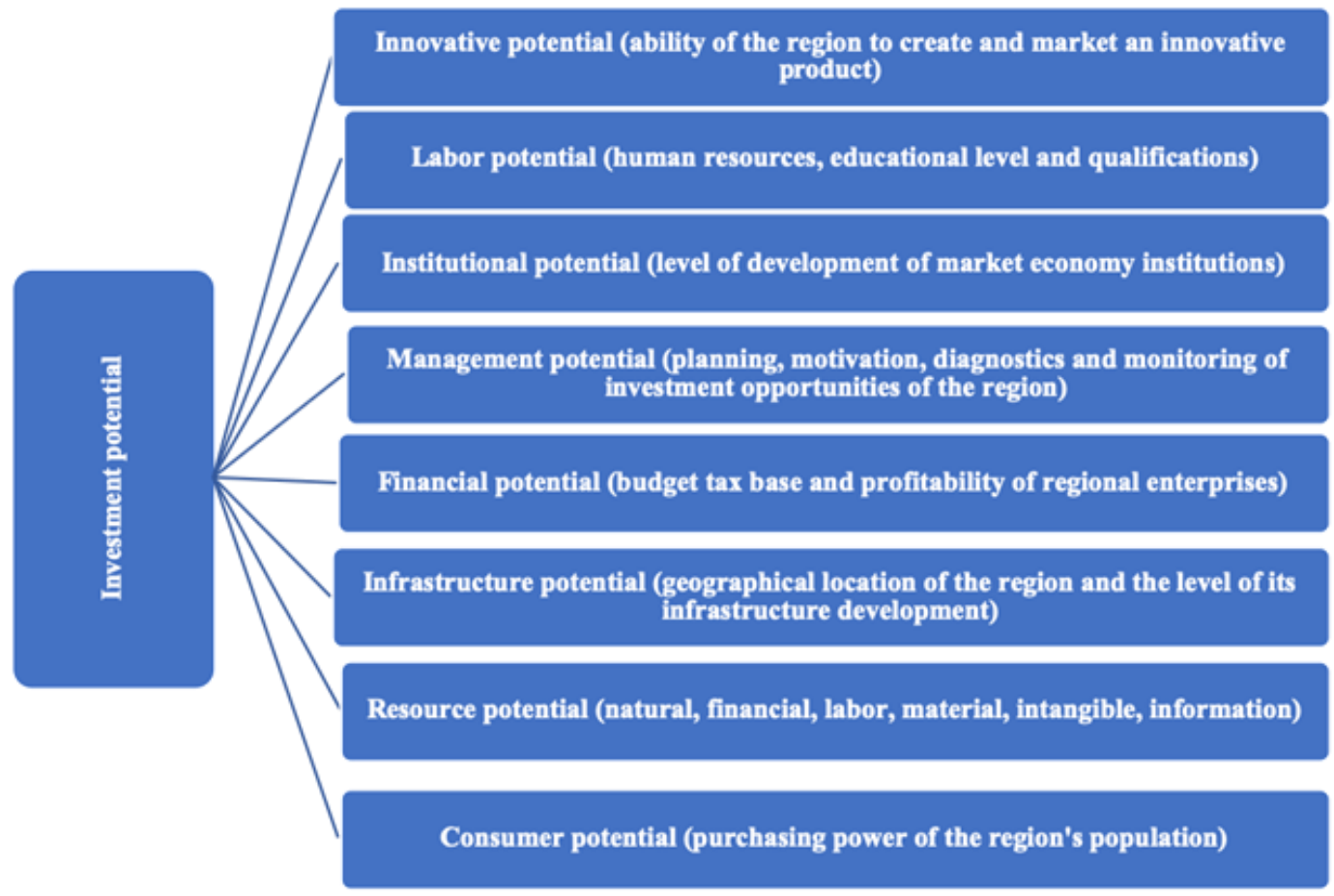

Figure 1. Structure of the investment potential of the region

Under the investment activity we will understand the volume, rate of increase (decrease) in investments to the region's economy and the efficiency of their use at the regional level. We believe that the investment attractiveness of the region is also significantly affected by the rate of investment inflow or outflow (primarily FDI), since this indicator characterizes the level of attractiveness of the region for investors who have already invested. In addition, the potential investor decides whether to invest or not, of great importance is the effectiveness of the development of the region already attracted investments. The fact is that the low efficiency of the use of investments signals, first of all, that the local business is not ready for their development, and sometimes about the lack of real objects of interest for a serious investor. Over time, this will transform into a situation at the regional level, when local authorities simply will not have real incentives to create favorable conditions for attracting investors. Undoubtedly, this aspect of the investment process should be taken into account when analyzing the investment attractiveness of the region. Therefore, we consider it appropriate to assess the investment attractiveness of the region taking into account investment activity in the region. 
Investment risk characterizes the uncertainty of the final result of the investment, or, in other words, determines the probability of loss or loss of return on investment. Investment activity in the region is associated with the following types of risks:

- administrative and legal

- political,

- economical,

- financial,

- social,

- environmental,

- technical,

- criminogenic,

- informational.

The general classification of investment risks is presented in Fig. 2.

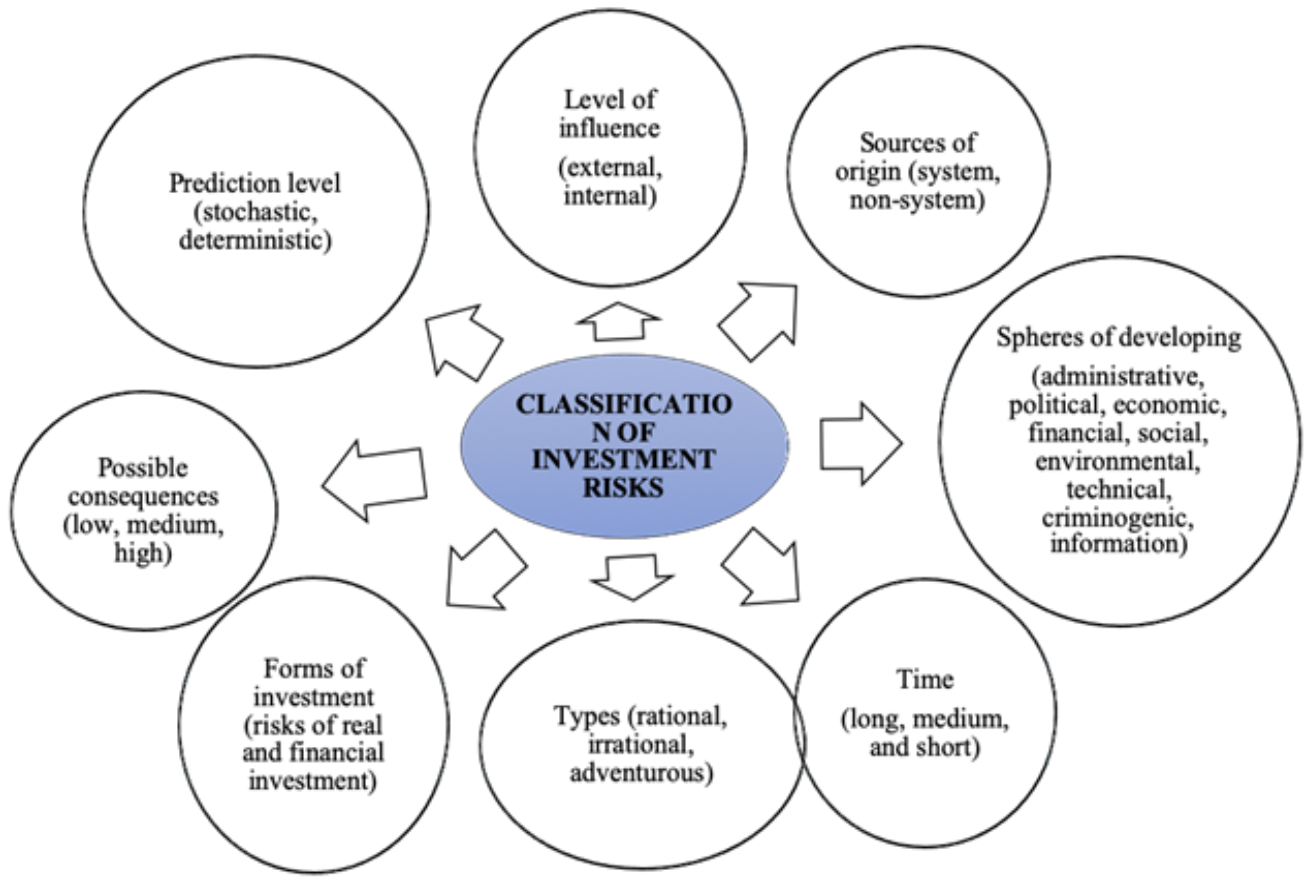

Figure 2. Classification of investment risks in the region

In our opinion, among the factors determining the investment climate in the region, the key place is taken by state administration at the macro and mesoscale. It is public administration that is a broad concept that can be effectively implemented in different ways. There are various types of governance, from political governance (the type of political system, constitutional order, relations between the state and society), economic governance (government institutions that regulate the economy, level of competition, property and contractual rights) and corporate governance (the legislative framework that defines corporate behavior, shareholder rights, transparency and disclosure, accounting standards). The situation is complicated by the fact that each individual aspect of management is connected with others, 
so decision-making on the assessment of any investment climate should be carried out on an individual basis.

\section{Conclusion}

In the economic literature there is no unambiguous interpretation of the concept of investment attractiveness of the region. This is a multifaceted concept and today there is no clear coherence between various economic and social actors regarding its unambiguous definition. Having analyzed the existing approaches to the interpretation of the terms "region's investment climate" and "region's investment attractiveness", the article proposed an approach to determining investment attractiveness as a function of the following variables: investment climate, investment activity, investment potential and investment risk. The paper also proposes a system for classifying the investment risks of the region and the structure of the investment potential of the region. According to the authors, among the factors determining the investment climate in the region, a special place is occupied by the system of public administration at the macro and mesoscale, since it is public administration that can be effectively implemented at the regional level in various ways.

\section{References}

Blank, I. (2006). Investment management: a training course for universities. Kiev: Elga. [in Russian].

Dollar, D., Hallward-Driemeier, M., and Mengistae, T., (2005). Investment Climate and Firm Performance in Developing Economies. Economic Development and Cultural Change, University of Chicago Press, vol. 54 (1), 1-31. [in English].

Erickson, R. (1987). Business Climate Studies: A Critical Evaluation. Economic Development Quarterly, 1 (1), 62-71. [in English].

Korenyuk, P., Kopil, E. (2018). Conceptual Approaches and Methods for determining the Investment Attractiveness of the National Economy. Economic Journal of Lesya Ukrainka Eastern European National University, 2 (14), 56-62. DOI: 10.29038/2411-4014-2018-02-5662. [in English].

Kuznetsova, S., Vakulich, M. (2017). Investment Climate Rating Evaluation: The Case of the Ukrainian Economy. Financial Risk and Management Reviews, 3 (3), 1-12. DOI: 10.18488 / journal.89.2017.31.1.12. [in English].

Lahimer, N. (2007). Location Theory, Business Climate and Foreign Direct Investment in Africa. Université Paris-Dauphine Center de Recherche: EURIsCO. [Electronic resource]. Retrieved from http://sugarhoover.co.uk/articulos/Lahimer.pdf. [in English].

Litvinova, V. (2014). Investment attractiveness. The investment climate of the region: on the issue of definitions and valuation. The Bulletin of the Financial University. [Electronic resource]. Retrieved from https://www.academia.edu/39270811/The_Investment_ Attractiveness_and_Investment_Climate_of_a_Region_to_the_Issue_of_Definition_and_Asse ssment. [in Russian].

Malko, K. (2015). Investment climate and investment attractiveness of Ukraine: factors of their formation in modern conditions. Actual problems of economy, 3 (165), 100-105. [in Ukrainian].

Nechitaylo, V. (2011). Investment potential and investment climate: formation and correlation features. Uzhgorod University Scientific Bulletin, Economy series, 2 (32). 97-103. [in Ukrainian]. 
Pokataeva, K. (2007). Theoretical aspects of defining the categories "Investment potential" and "Investment attractiveness". Scientific and Technical Collection "Municipal Economy of Cities", 75, 262-268. [in Ukrainian].

Tretyak, N. (2013). Factors of formation of investment climate in Ukraine. Financial Space, 3, 165-170. [Electronic resource]. Retrieved from http://nbuv.gov.ua/UJRN/ Fin_pr_2013_3_24. [in Ukrainian]. 